\title{
Performance Evaluation and Field Application of Prefabricated Grass-Planting Concrete Blocks with Concave-Convex Construction for Mid-Sized and Small River Revetment Projects
}

\author{
Hui Jiang*, Yao Liu \\ National and Local Joint Engineering Laboratory of Hydraulic Engineering Safety and Efficient Utilization of Water \\ Resources in Poyang Lake Basin, Nanchang Institute of Technology, Nanchang 330099, China
}

Received: 4 February 2021

Accepted: 9 June 2021

\begin{abstract}
As a kind of material used in river revetments, the revetment concrete blocks are required to have satisfactory strength, scouring resistance, and good vegetation coverage. In this paper, prefabricated grass-planting concrete blocks that are suitable for the ecological revetment of medium and small-sized rivers are proposed and innovatively designed. The blocks are made with concave and convex structures of random porous concrete material, which can be jointed and inlaid to form a three-dimensional slope with vegetation function. The performances and advantages of prefabricated grass-planting concrete are evaluated. Four kinds of precast blocks are proposed. The flow velocity reduction, soil conservation, and scouring resistance of these blocks are analyzed quantitatively through physical modeling and field application. The results show that the four blocks can effectively reduce the near-shore flow velocity and decrease the level of scouring on the slope surface. The rate of scouring reduction of the different prefabricated blocks placed on the slope was in the range of $35 \%-43 \%$; thus, the results were similar. Through application on a riverbank, this concave-convex revetment structure shows excellent improvement in scouring resistance and soil conservation, with average vegetation coverage up to 95\%. Prefabricated grass-planting concrete blocks can be used as riverbank revetment materials.
\end{abstract}

Keywords: prefabricated grass-planting concrete, ecological revetment, scouring resistance, soil conservation, river

*e-mail: jnhuily@163.com 


\section{Introduction}

Rigid materials such as masonry, cast-in-place concrete, and blank concrete walls, which can effectively resist floods and protect the riverbank, are typically used in river revetments. However, the rigid material and material structure are compact, and make it difficult for plants to grow, which blocks the exchange between the river and the riparian zone. The river ecosystem is destroyed with a rigid material slope, and the river fails in its role as an ecological corridor. Grass-planting concrete, e.g., porous concrete with a planting function [1], is of particular interest and has found practical application as a river revetment material. Its performance can strengthen the growing conditions for plants. The plant roots can freely pass through its continuous voids, and water, fertilizer soil, air, and space for growth are provided in the void [2]. The effective porosity of grass-planting concrete is usually more than $20 \%$ [3]. Some researchers have carried out an impact analysis of the components and mix ratio, the basic mechanical properties, and void and alkaline testing of grass-planting concrete [4-7]. It has been found that the strength viability of porous concrete depends not only on the void, but also on the size of the coarse aggregate and the water-cement ratio [8-10]. To meet void requirements, the strength of concrete may be reduced by using less mortar [11], and other materials such as limestone powder, ganister powder, and fly ash are used to replace cement and achieve high compressive and tensile strength of the concrete [1214]. Polymer may be added to porous grass-planting concrete and paving materials $[15,16]$. The alkalinity of concrete comes from the cement, and it increases with an increased content of cement. The high alkalinity of concrete is unfit for growing plants [17, 18]. A 40$60 \%$ by weight replacement of cement with fine-powder blast furnace slag effectively reduces the cement content and alkalinity of concrete [19]. Calcium aluminate cement with a lower $\mathrm{pH}$ than ordinary Portland cement was used [20]. These studies facilitate the application of grass-planting concrete. However, there are some problems. Although a thin covering of soil on the surface of grass-planting concrete can provide plants with water, air, and nutrients, it can be scoured off under flood conditions, especially if plant roots have not passed through the concrete to reach the bank foundation. Recently, grass-planting concrete revetments have been mostly in the form of concrete outer frames with cast-in-place grass-planting concrete. It is easy for large concrete blocks to crack because of the uneven settlement of the bank foundation and the low strength of concrete. At the same time, it is difficult to control the pouring quality onsite, due to unsteady temperature and humidity during the curing period. The stability of the riverbank slope and the growth of planting are directly affected by these factors, which significantly restricts the production and application of grass-planting concrete in rivers.
In this study, new types of prefabricated grassplanting concrete blocks with concave-convex construction are put forward, and the revetment performances are tested. Different from common prefabricated concrete [21, 22], prefabricated grassplanting concrete is a small member that uses random porous concrete as the skeleton, which is a mosaic spliced to form a three-dimensional slope. The concrete voids are filled with suitable soil mixed with grass seeds. The roots of herbaceous plants grow in the concrete and reach the shore foundation, unifying the herbaceous plants, concrete, and shore foundation. Optimization of the structural design and physical model testing of prefabricated grass-planting concrete blocks was carried out, flow velocity was reduced, and soil conservation and scouring resistance were evaluated. Furthermore, the physical properties and vegetational performance of the concrete were applied and validated in situ.

\section{Material and Methods}

\section{Materials and Specimens}

\section{Materials}

Commercial ordinary Portland cement P.O 42.5 [23] and ganister powder were selected as the cementitious materials for preparing prefabricated revetment concrete blocks, and its properties are listed in Table 1. Coarse aggregates with gradations of $10-20 \mathrm{~mm}, 15-30 \mathrm{~mm}$, and $20-40 \mathrm{~mm}$ were tested for making concrete, and their physical properties are presented in Table 2 . Natural river sand was used as a fine aggregate, with an apparent density of $2650 \mathrm{~kg} / \mathrm{m}^{3}$, a bulk density of $1530 \mathrm{~kg} / \mathrm{m}^{3}$, and a fineness modulus of 2.15 . The ecoconcrete additive used was SR-4 which is liquid, and its main ingredients were $\mathrm{CaCO}_{3}, \mathrm{SiO}_{2}$, and other inorganic materials. The SR-4 additive, which has a density of

Table 1. Properties of Portland cement P.O 42.5.

\begin{tabular}{|c|c|}
\hline Properties & P.O 42.5 \\
\hline Density $\left(\mathrm{kg} / \mathrm{m}^{3}\right)$ & 3085 \\
\hline Blaine fineness $\left(\mathrm{m}^{2} / \mathrm{kg}\right)$ & 358.2 \\
\hline Setting time(min) \\
\hline Initial & 195 \\
\hline Final & 235 \\
\hline Compressive strength (MPa) \\
\hline $3 \mathrm{~d}$ & 27.7 \\
\hline $28 \mathrm{~d}$ & 49.8 \\
\hline Flexural strength (MPa) \\
\hline $3 \mathrm{~d}$ & 5.9 \\
\hline $28 \mathrm{~d}$ & 8.8 \\
\hline
\end{tabular}


Table 2. Properties of coarse aggregate.

\begin{tabular}{|c|c|c|c|}
\hline Properties & \multicolumn{3}{|c|}{ Coarse aggregate } \\
\hline Aggregate gradation $(\mathrm{mm})$ & $10-20$ & $15-30$ & $20-40$ \\
\hline Apparent density $\left(\mathrm{kg} / \mathrm{m}^{3}\right)$ & 2750 & 2755 & 2760 \\
\hline Compact packing density $\left(\mathrm{kg} / \mathrm{m}^{3}\right)$ & 1460 & 1510 & 1560 \\
\hline Sand content $(\%)$ & 0.91 & 0.80 & 0.45 \\
\hline Needle flake content (\%) & 11.00 & 10.50 & 1.00 \\
\hline Water absorption (\%) & 13.50 & 11.30 & 10.55 \\
\hline Crushing value (\%) & 9.50 & 6.28 & 6.85 \\
\hline
\end{tabular}

$1.045 \mathrm{~kg} / \mathrm{L}$, can efficiently improve the compressive strength and durability of the formed blocks. Ganister powder with an average size of $0.13 \mu \mathrm{m}$ and specific surface area of $19.0 \mathrm{~m}^{2} / \mathrm{g}$ was selected to increase the strength property of the prefabricated revetment concrete blocks.

\section{Specimens}

The target compressive strength of blocks was $7 \mathrm{MPa}$ or higher, the target void ratio was more than $20 \%$, and the target $\mathrm{pH}$ value was less than 9 for mid-sized and small rivers. To achieve the voids in the grass-planting concrete, a gap-graded aggregate was used. The design mix proportion of the grass-planting concrete was optimized by orthogonal testing. Key testing factors were analyzed, such as crushed stone grades of 10-20 mm, 15-30 mm, and 20-40 mm, design porosities of $20 \%$ and $25 \%$, liquid-solid ratios of $0.20,0.25,0.30$ with liquid components including water and SR-4 and solid components including cement, sand, and ganister, and $3 \mathrm{~L} / \mathrm{m}^{3}$ of eco-concrete additive SR-4 and $15 \mathrm{~g} / \mathrm{m}^{3}$ of Ganister powder. Component contents of grassplanting concrete were computed by the volume method [24]. The design mix proportions of prefabricated grassplanting concrete are shown in Table 3.

\section{Methods}

\section{Structural Design}

To evaluate the physical and mechanical properties of concrete blocks, different types of prefabricated grass-planting concrete blocks were innovatively designed. The design and calculation of the structure types, sizes, and embedding shapes of the specimens were carried out, and detailed structures were considered on the basis of structural analysis and engineering experience.

Table 3. Mix proportions of grass-planting concrete.

\begin{tabular}{|c|c|c|c|c|c|c|c|c|c|}
\hline No. & $\begin{array}{c}\text { Coarse aggregate } \\
\text { grade } \\
(\mathrm{mm})\end{array}$ & $\begin{array}{l}\text { Target } \\
\text { voids } \\
(\text { vol } \%) \\
\end{array}$ & $\begin{array}{l}\text { Liquid- } \\
\text { solid ratio }\end{array}$ & $\begin{array}{c}\text { Crushed stone } \\
\text { content } \\
\left(\mathrm{kg} / \mathrm{m}^{3}\right)\end{array}$ & $\begin{array}{l}\text { Water } \\
\left(\mathrm{L} / \mathrm{m}^{3}\right)\end{array}$ & $\begin{array}{l}\text { Cement content } \\
\qquad\left(\mathrm{kg} / \mathrm{m}^{3}\right)\end{array}$ & $\begin{array}{l}\text { Sand } \\
\text { content } \\
\left(\mathrm{kg} / \mathrm{m}^{3}\right)\end{array}$ & $\begin{array}{l}\mathrm{SR}-4 \\
\left(\mathrm{~L} / \mathrm{m}^{3}\right)\end{array}$ & $\begin{array}{l}\text { Ganister } \\
\text { powder } \\
\left(\mathrm{kg} / \mathrm{m}^{3}\right)\end{array}$ \\
\hline 1 & \multirow{6}{*}{$10 \sim 20$} & 20 & \multirow{2}{*}{0.2} & \multirow{2}{*}{1430} & 101 & 253 & 253 & 3 & 15 \\
\hline 2 & & 25 & & & 83 & 208 & 208 & 3 & 15 \\
\hline 3 & & 20 & \multirow{2}{*}{0.25} & \multirow{2}{*}{1430} & 117 & 232 & 232 & 3 & 15 \\
\hline 4 & & 25 & & & 96 & 190 & 190 & 3 & 15 \\
\hline 5 & & 20 & \multirow{2}{*}{0.3} & \multirow{2}{*}{1430} & 132 & 218 & 218 & 3 & 15 \\
\hline 6 & & 25 & & & 109 & 179 & 179 & 3 & 15 \\
\hline 7 & \multirow{6}{*}{$15 \sim 30$} & 20 & \multirow{2}{*}{0.2} & \multirow{2}{*}{1480} & 95 & 237 & 237 & 3 & 15 \\
\hline 8 & & 25 & & & 77 & 192 & 192 & 3 & 15 \\
\hline 9 & & 20 & \multirow{2}{*}{0.25} & \multirow{2}{*}{1480} & 109 & 218 & 218 & 3 & 15 \\
\hline 10 & & 25 & & & 89 & 176 & 176 & 3 & 15 \\
\hline 11 & & 20 & \multirow{2}{*}{0.3} & \multirow{2}{*}{1480} & 124 & 204 & 204 & 3 & 15 \\
\hline 12 & & 25 & & & 101 & 166 & 166 & 3 & 15 \\
\hline 13 & \multirow{6}{*}{$20 \sim 40$} & 20 & \multirow{2}{*}{0.2} & \multirow{2}{*}{1530} & 89 & 222 & 222 & 3 & 15 \\
\hline 14 & & 25 & & & 71 & 177 & 177 & 3 & 15 \\
\hline 15 & & 20 & \multirow{2}{*}{0.25} & \multirow{2}{*}{1530} & 102 & 203 & 203 & 3 & 15 \\
\hline 16 & & 25 & & & 82 & 162 & 162 & 3 & 15 \\
\hline 17 & & 20 & \multirow{2}{*}{0.3} & \multirow{2}{*}{1530} & 116 & 191 & 191 & 3 & 15 \\
\hline 18 & & 25 & & & 93 & 152 & 152 & 3 & 15 \\
\hline
\end{tabular}


The size, length, and minimum thickness of the prefabricated block structures are mainly related to the flow velocity and slope. The minimum thickness of the prefabricated blocks is given by Eq. (1), and the detailed structural design was carried out in combination with engineering experience and the stability of the inlay.

$$
t=K \frac{0.11(2 h)}{\left(\gamma_{c}-\gamma_{w}\right) \cos \alpha \sqrt{b}}
$$

...where $t$ is the thickness of the prefabricated blocks (m), $K$ is the safety factor, which can be determined to be 1.10 based on the safety factor of a general slope according to the GB 550286 standard [25], $2 h$ is the design wave height $(\mathrm{m}), \gamma_{c}$ is the bulk density of concrete $\left(\mathrm{t} / \mathrm{m}^{3}\right), \gamma_{w}$ is the bulk density of water $\left(\mathrm{t} / \mathrm{m}^{3}\right)$, $b$ is the length of blocks along the bank slope (m), and $\alpha$ is the angle between the bank slope and a horizontal line; $\alpha$ is equal to $28.6^{\circ}$ when the slope of the riverbank is $1: 2$.

It is difficult to provide sufficient water and soil until the grass has grown in riverbanks; therefore, concaveconvex construction is proposed in this study for the near-shore side of the slope to decrease flow velocity and prevent flow-down of the soil.

In the design process, the following steps are required. First, the concave-convex height difference must be set according to the hydraulic conditions of the river and the requirement of grass growth, while the thickness of the concave structure should be ensured to meet the requirements of the minimum thickness of revetment blocks; the thicker the concrete, the more difficult the growth of grass. Second, it is necessary to design different shapes for the concrete blocks to be sufficiently embedded, and some bayonets should be designed; the more stably the blocks are embedded with each other, the more conducive to the stability of the riverbank. Third, structural design cannot be too complex, as the production and construction of components of complex structures are not favorable. Moreover, the concrete section cannot be too large or too small, because the concrete could easily break during the construction process. Therefore, it is necessary to optimize and improve the components via practice. For example, the shape of the built-in blocks was a cross, the middle regular part of which was designed to be convex. Though built-in cross blocks have a simple structure and are easy to make, the blocks can be firmly inlaid with each other. Different types of blocks were designed to help the grass to settle easily and flourish until its roots could pass through the member. Assembled grass-planting concrete test blocks are manufactured according to the design size, as follows: The concrete mixed from raw materials was poured into a wooden mold and manufactured by tamping via the use of steel chisels and a manual layering method, then cured at the standard condition of $20 \pm 2^{\circ} \mathrm{C}$ and relative humidity above $95 \%$. Member production was complete after 28 days.
Fig. 1 shows the design of four types of prefabricated grass-planting concrete blocks, which are, respectively, built-in I-shaped blocks (type I), built-in regular hexagon blocks (type II), built-in cross blocks (type III), and built-in square blocks (type IV). Types I, II, and IV have prefabricated blocks of two different thicknesses. The thickness of the tall member is $10 \mathrm{~cm}$, and that of the short member is $8 \mathrm{~cm}$, thus the surface of the concave-convex structure forms a quincunx with a $2 \mathrm{~cm}$ height difference. Type III is a single concaveconvex cross member with a $5 \mathrm{~cm}$ height difference. In order to further strengthen the stability of the blocks on the riverbank, holes with a $7.5 \mathrm{~cm}$ square are designed in the middle of type II and IV blocks for planting grass with strong roots, such as Vetiveria, which plays a role in plant reinforcement [26].

\section{Strength}

Specimens were prepared in a cube steel mold of $150 \times 150 \times 150 \mathrm{~mm}$ for compressive strength testing, and $100 \times 100 \times 400 \mathrm{~mm}$ for flexural strength testing [27], and then cured at the standard condition of $20 \pm 2^{\circ} \mathrm{C}$ and relative humidity above $95 \%$ for $28 \mathrm{~d}$. In order for the surface of the specimens to be in close contact with the equipment, the super-surface and undersurface were smoothed by the mortar before the test. Each of the three specimens were manufactured corresponding to each set of compressive or flexural data, and the average values of strength were calculated for each dataset.

Void ratio

Voids are the main property of grass-planting concrete that helps the grass to grow. Void ratio $\left(P_{\mathrm{e}}\right)$ is the rating of accessible voids, which can be evaluated with Eq. (2) on the $28^{\text {th }}$ day using the volume difference [28]. The volume of cube specimens of $150 \times 150 \times 150$ $\mathrm{mm}\left(V_{0}\right)$ is computed, a certain amount of water is added to the water container, and the volume $\left(V_{1}\right)$ of the water is calculated. Thereafter, the test specimen is slowly placed into the water container. When the water surface is stable, the water surface value is measured and the volume $\left(V_{2}\right)$ is calculated.

$$
P_{e}=\left(1-\frac{V_{2}-V_{1}}{V_{0}}\right) \times 100 \%
$$

The specimens were prepared such that the pores were saturated with water as much as possible. After water curing for $1 \mathrm{~d}$ before the test, the water-cured specimens were dried for $24 \mathrm{~h}$ to ensure that they were absolutely dry, and the void ratios were then measured.

\section{Alkalinity}

The alkalinity of grass-planting concrete was tested according to a previously reported method [29]. Concrete specimens with a volume of $150 \times 150 \times 150 \mathrm{~mm}$ were constructed for alkalinity testing at a temperature of $20 \pm 2^{\circ} \mathrm{C}$ for $28 \mathrm{~d}$. The concrete specimens were placed 
a) Type I

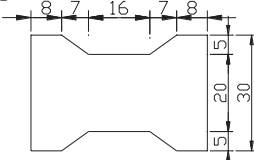

Plan view of

high member

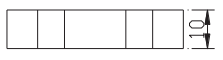

Sectional view of high member

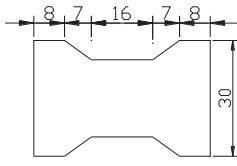

Plan view of

low member

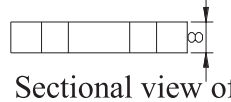

low member b) Type II

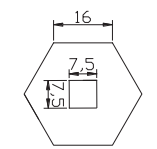

Plan view of high member

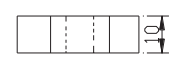

Sectional view of high member

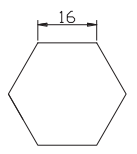

Plan view of low member

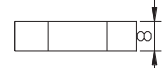

Sectional view of low member

c) Type III

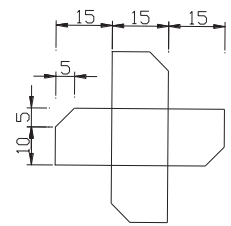

Plan view

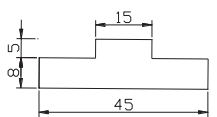

Sectional view

d) Type IV

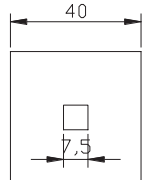

Plan view of high member

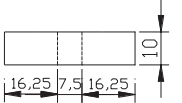

Sectional view of high member

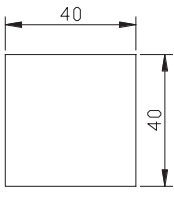

Plan view of low member

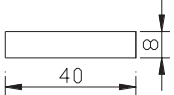

Sectional view of low member

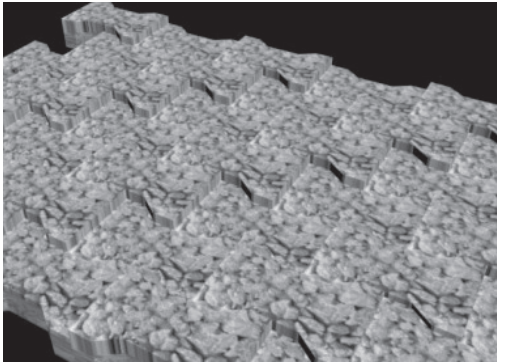

3D rendering after setting blocks

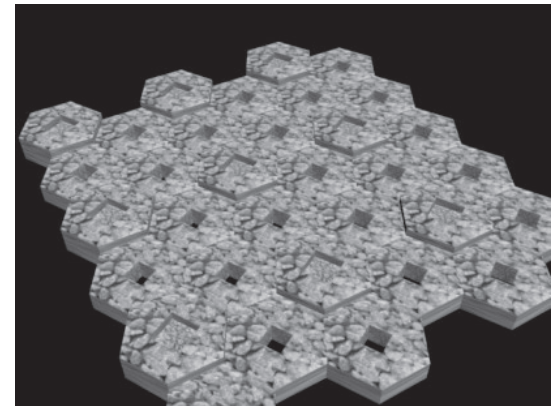

$3 \mathrm{D}$ rendering after setting blocks

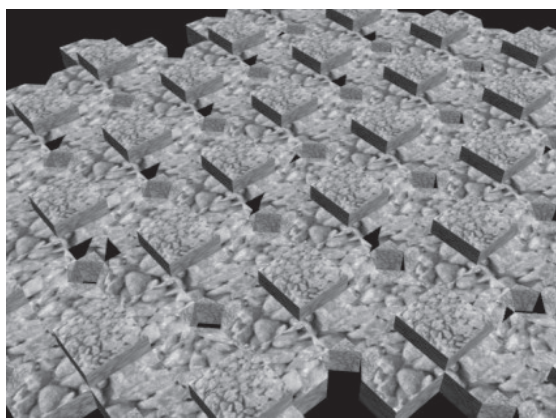

3D rendering after setting blocks

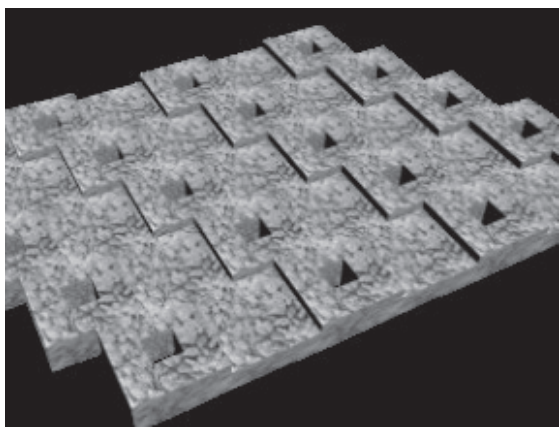

$3 \mathrm{D}$ rendering after setting blocks

Unit: $\mathrm{cm}$

Fig. 1. Structural design diagram of prefabricated grass-planting concrete blocks.

in water containers, and $3 \mathrm{~L}$ of distilled water was added into these containers to immerse the specimens. After immersion for $24 \mathrm{~h}$, the test water was retrieved with a small cup, and the $\mathrm{pH}$ value was measured with a $\mathrm{pH}$ meter. The $\mathrm{pH}$ value of the soaking solution was measured using a laboratory-grade $\mathrm{pH}$ meter (PHS$3 \mathrm{E}$, China). The container was refilled with $3 \mathrm{~L}$ of pure deionized water after each test.

\section{Flow Velocity Difference}

The concave and convex surfaces of the concrete blocks can guide the flow of water and change the turbulent status of the flow to reduce the scouring of water on the surface soil and the presence of soil in the voids of the concrete. The flow velocity difference is an expression of key dynamic parameters as well 
as the flow resistance and Reynolds number. The flow velocity difference denotes subtraction between the flow velocity of the convex and concave area of the blocks. In this experiment, flow velocity was measured on the convex and concave area of the blocks before the concrete was filled and poured with soil, and the mean flow velocity difference was the mean value of three measuring positions on each frame of the tested blocks. The positions of the measurement points are shown in Fig. 1. The velocity was measured with the flow velocity meter.

\section{Scouring Resistance}

The slope of a bank (i), which is the ratio of elevation difference and horizontal distance of the slope, is usually in the range of 1:2 to $1: 3$ in ecological projects of mid-sized and small rivers. Soil is easily lost when the slope is less than $1: 2$, so slopes of $1: 2$ or $1: 3$ were set in the experiment. Flow velocity was measured during the research of mid-sized and small rivers, and was usually less than $3.0 \mathrm{~m} / \mathrm{s}$, so scouring models were set with a flow velocity $(V)$ of $0.7 \mathrm{~m} / \mathrm{s}, 1.2 \mathrm{~m} / \mathrm{s}$, and $2.0 \mathrm{~m} / \mathrm{s}$. The blocks were placed in constant water level in the rivers, and scouring models were tested with a water depth $(H)$ of $0.5 \mathrm{~m}$ or $1.0 \mathrm{~m}$, as well as a water depth between the top of the wooden frame and the water surface (see Fig. 2).

To implement the scouring experiments, slope equipment with a $1 \mathrm{~m}^{2}$ custom-made wooden frame was designed and prefabricated. The prefabricated blocks were assembled into a wooden frame. The farmland soil with the flow was poured into the revetment concrete blocks, and the soil cover with the humidity of $21 \%$ was filled and manually compacted by rammer to the level of the convex surface of the concrete. The experimental design is shown in Fig. 2.

Scouring tests were carried out on the four types of assembled blocks and a cast-in-place concrete block.
Cast-in-place concrete test was a comparison with that of concave convex structures blocks. It directly poured the porous concrete into the testing frame, and a grassplanting smoothing concrete block without concave convex surface was formed by flapping and flattening process. The water flowing through the surface of the wooden frame was even and smooth without obvious local disturbance. The scouring level of different blocks, which varied with the scouring time under the same test conditions, was measured. The soil scouring level was measured at 10,20, and $40 \mathrm{~min}$, and the amount of scoured soil was measured by weighing method. Before the test, the soil was saturated by adding water, and the total weight of wood frame, concrete and soil was measured as the initial total weight. After each scouring test, the total weight is measured under the soil saturation condition. the amount of cumulative scoured soil was computed with the difference between the initial total weight and the total weight of each test.

The experiment scheme for scouring resistance was planned with the factors of water level, flow velocity, and slope. Nine test cases are shown in Table 4.

\section{Results and Discussion}

\section{Strength}

Fig. 3 shows that the average $28 \mathrm{~d}$ compressive strength of specimens with a 20-40 $\mathrm{mm}$ coarse aggregate grade is less than $6.00 \mathrm{MPa}$, and the maximum value is $7.10 \mathrm{MPa}$; the average $28 \mathrm{~d}$ flexural strength is $2.70 \mathrm{MPa}$, and the maximum value is 3.10 $\mathrm{MPa}$. Compared with specimens using small and medium grade aggregate, the strength of the specimens decreases mainly because the larger the aggregate grade and the smaller the specific surface area, the smaller the total cementing area, and the strength cannot meet

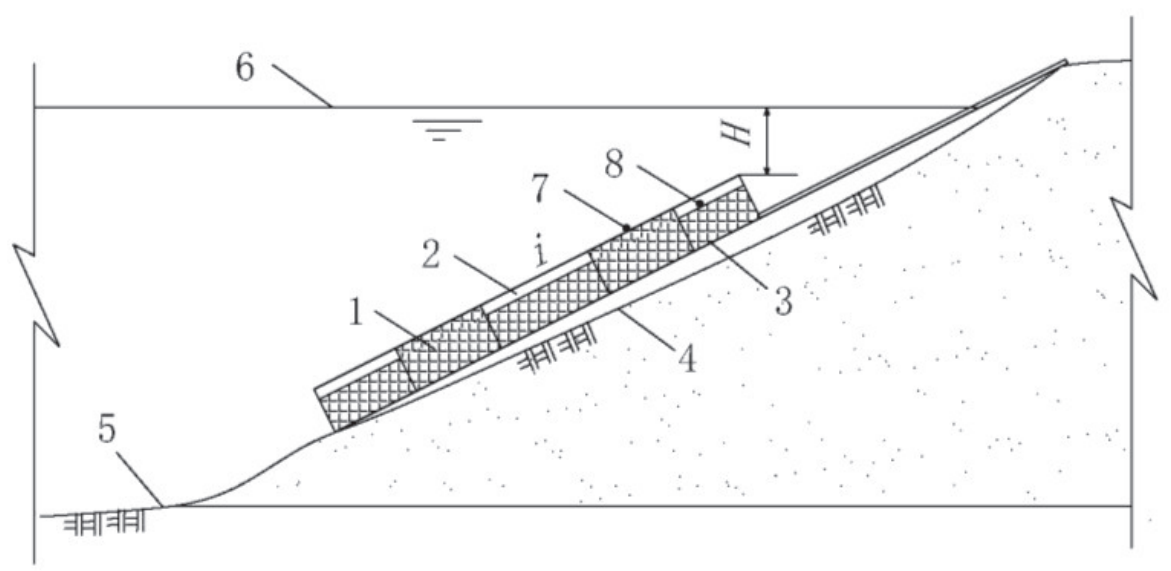

Fig. 2. Test design of scouring resistance. 1. Prefabricated grass planting concrete; 2. Casing soil; 3. Wooden frame; 4. bank-based; 5. Riverbed; 6 . Water surface; 7 . The measurement point of the flow velocity in the convex surface of the concrete blocks before the concrete was filled and poured with soil; 8. The measurement point of the flow velocity in the concave surface of the concrete blocks before the concrete was filled and poured with soil. $\mathrm{H}$ : The height from the water surface to the top of the wooden frame 
Table 4. Test cases of scouring resistance.

\begin{tabular}{|c|c|c|c|c|}
\hline Case & Member types & Water level (m) & Flow velocity (m/s) & Slope \\
\hline Case 1 & Type I & 0.5 & 1.2 & $1: 2$ \\
\hline Case 2 & Type II & 0.5 & 1.2 & $1: 2$ \\
\hline Case 3 & Type III & 0.5 & 1.2 & $1: 2$ \\
\hline Case 4 & Type IV & 0.5 & 1.2 & $1: 2$ \\
\hline Case 5 & Cast-in-place concrete & 0.5 & 1.2 & $1: 2$ \\
\hline Case 6 & Type II & 1.0 & 1.2 & $1: 2$ \\
\hline Case 7 & Type II & 0.5 & 0.7 & $1: 2$ \\
\hline Case 8 & Type II & 0.5 & 2.0 & $1: 3$ \\
\hline Case 9 & Type I & 0.5 & 1.2 & \\
\hline
\end{tabular}

the basic target requirements for the compressive strength of mid-sized and small rivers. The average $28 \mathrm{~d}$ compressive strength and $28 \mathrm{~d}$ flexural strength of the specimens with a small aggregate grade reached $8.40 \mathrm{MPa}$ and $3.10 \mathrm{MPa}$, respectively, and their maximum values were $12.90 \mathrm{MPa}$ and $4.10 \mathrm{MPa}$, respectively. Therefore, a coarse aggregate grade of $15-30 \mathrm{~mm}$ is suitable for grass-planting concrete with the goal of obtaining a compressive strength of more than $7 \mathrm{MPa}$ in mid-sized and small rivers.

\section{Void Ratio}

Fig. 4 shows that the void ranges of all test specimens vary from $19.0 \%$ to $20.4 \%$, with an average of $19.8 \%$, which is close to the target void of $20 \%$. The void ranges from $23.2 \%$ to $24.8 \%$, with an average of $24.2 \%$, which is close to the target void of $25 \%$. The compressive strength of concrete decreases with an increase in void. The results show that the void is closely related to the compressive strength.

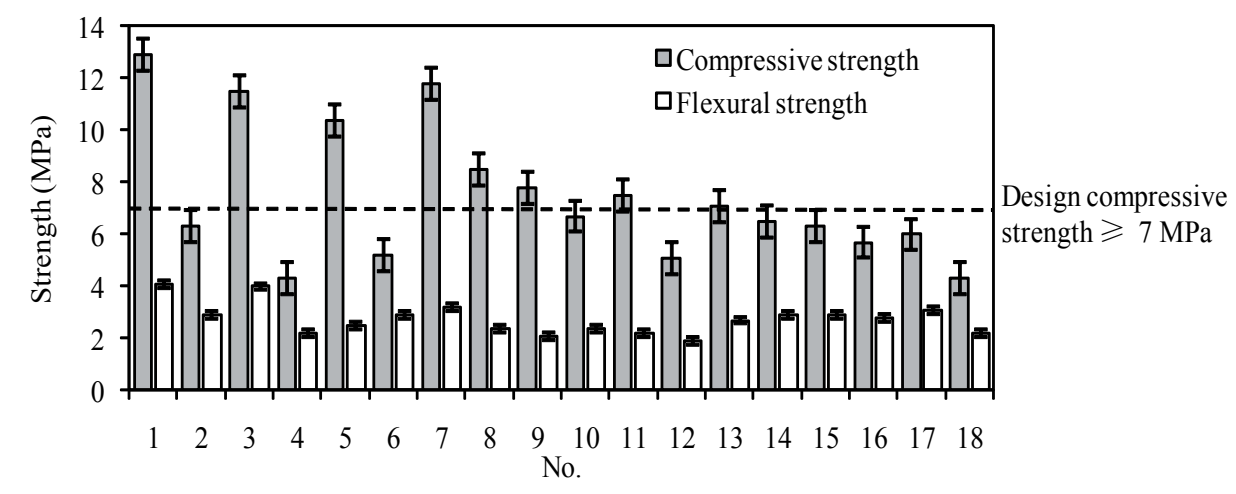

Fig. 3. Strength of grass-planting concrete specimens.

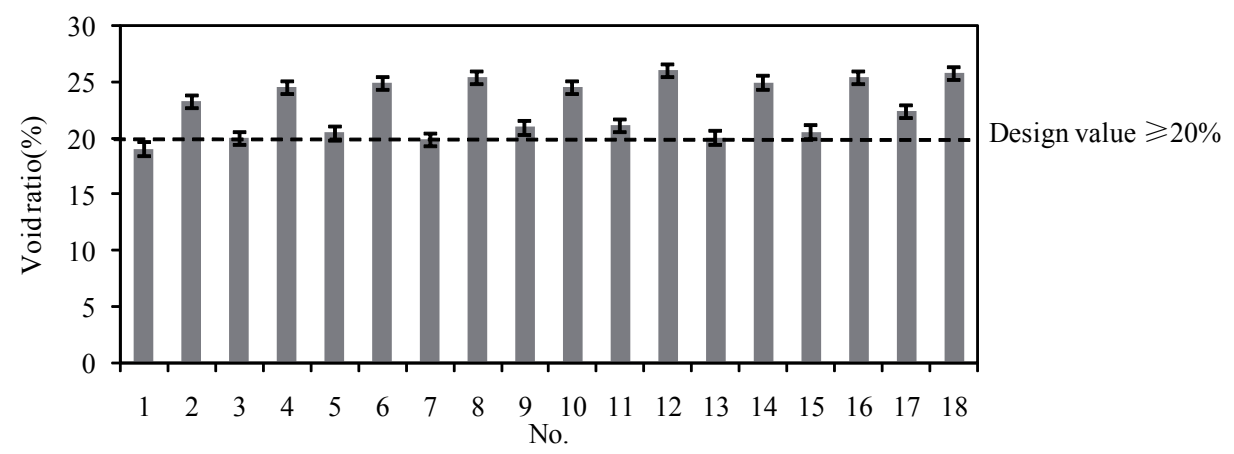

Fig. 4.Void ratio of grass-planting concrete specimens. 


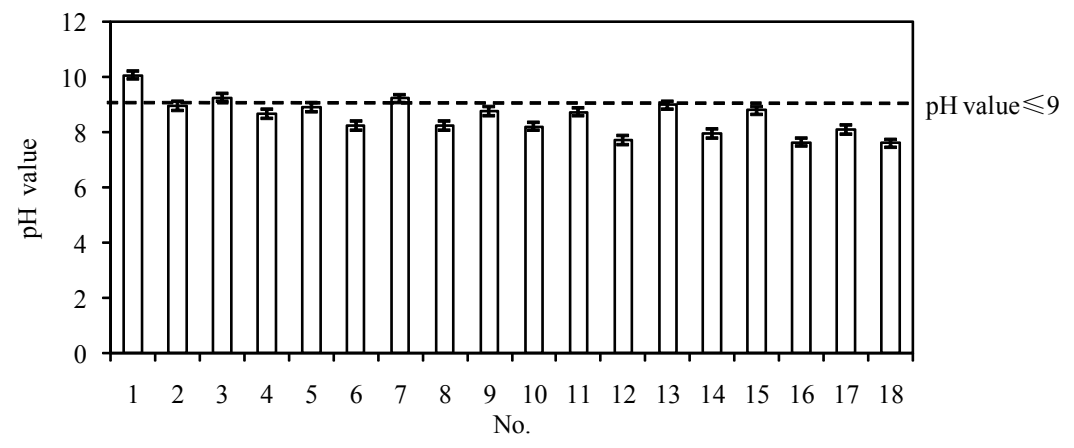

Fig. 5. The $\mathrm{pH}$ value of grass-planting concrete specimens.

\section{Alkalinity}

Fig. 5 shows that the $\mathrm{pH}$ values of concrete measured for all test specimens varied from 7.60 to 10.07 , and the average $\mathrm{pH}$ value was 8.56 . The $\mathrm{pH}$ value is affected by the hydration reaction of cement, and an increase in $\mathrm{pH}$ value is observed with the cement content increase. The $\mathrm{pH}$ value was as high as 9.0 when the cement content was greater than $230 \mathrm{~kg} / \mathrm{m}^{3}$.

\section{Flow Velocity Difference}

The $10^{\text {th }}$ mix of 18 mixes was selected for the construction of the prefabricated grass-planting concrete blocks and cast-in-place concrete. Figure 6 shows that flow velocity through different blocks is decreased due to the convex and concave areas. The built-in regular hexagon member shows the greatest effect of decreased flow velocity with an increase in flow resistance. The difference between mean flow velocity measured on the convex and concave area of blocks was $0.27 \mathrm{~m} / \mathrm{s}$, whereas the water level was $0.5 \mathrm{~m}$. The slope formed by the built-in cross member has the second-highest water scouring resistance, with a mean flow velocity difference of $0.23 \mathrm{~m} / \mathrm{s}$. The lowest value is for the built-in I-shaped member, with a mean flow velocity difference of $0.17 \mathrm{~m} / \mathrm{s}$. With the increase in the water level, the

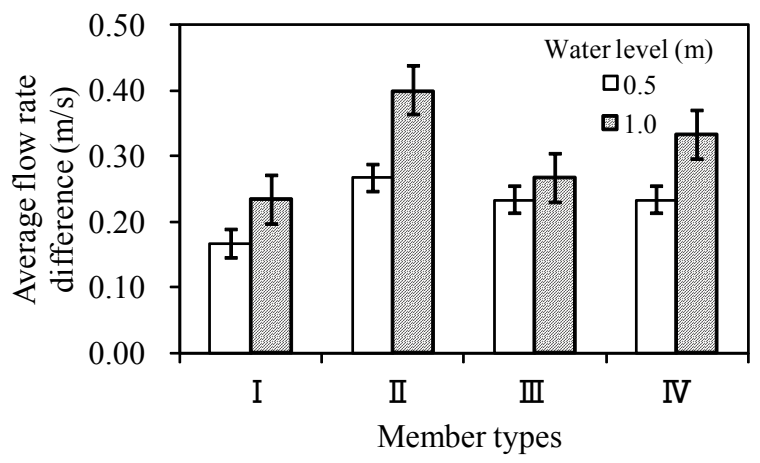

Fig. 6. Average flow rate difference between different prefabricated grass-planting concrete under different water levels. flow velocity difference for each member increases, and the water level is positively correlated with the flow resistance coefficient, which indicates that as the water level increases, more flow energy is consumed to overcome the resistance. The flow velocity difference between different blocks increases at different rates as the water level varies from $0.5 \mathrm{~m}$ to $1.0 \mathrm{~m}$. The built-in regular hexagon member shows the greatest reduction in flow velocity difference, with an increase of $0.13 \mathrm{~m} / \mathrm{s}$, and the built-in cross member shows the least reduction, with a flow velocity difference increase of $0.04 \mathrm{~m} / \mathrm{s}$. Thus, the flow velocity of water decreases for different prefabricated grass-planting concrete blocks to different extents, which shows that the decrease in flow velocity and construction shape are closely related.

\section{Scouring Resistance}

The rate of scouring reduction $\left(R_{\mathrm{s}}\right)$ was calculated by Eq. (3): $R_{\mathrm{s}}=(b-a) / b \times 100 \%$, where $a$ is the amount of cumulative scouring with the prefabricated blocks laid on the slope, and $b$ is the amount of cumulative scouring with the cast-in-place smoothing concrete laid on the slope.

Fig. 7 shows that the amount of erosion per 10-20 min for cast-in-place smoothing concrete changes little under the test conditions with a water level of $0.5 \mathrm{~m}$, bank slope of $1: 2$, and flow velocity of $1.2 \mathrm{~m} / \mathrm{s}$. The erosion level of the prefabricated grass-planting concrete blocks increased rapidly at first and then slowed down. The scouring level for the five types of blocks grew rapidly while the surface soil was scoured in $10 \mathrm{~min}$. After a $20 \mathrm{~min}$ time period, the cumulative scouring levels of the slope with cast-in-place concrete are distinct larger than the slopes with prefabricated blocks. After $40 \mathrm{~min}$, under the conditions of a $0.5-\mathrm{m}$ water level and a water flow rate of $1.2 \mathrm{~m} / \mathrm{s}$, the average rate of scouring reduction with the four types of prefabricated blocks was found to be $39 \%$, which demonstrates that the prefabricated blocks played a role in water scouring resistance. However, Fig. 8 demonstrates that the rate of scouring reduction with different prefabricated blocks laid on the slope was in the range of $35 \%-43 \%$ after $40 \mathrm{~min}$; thus, the results were similar. The slopes 


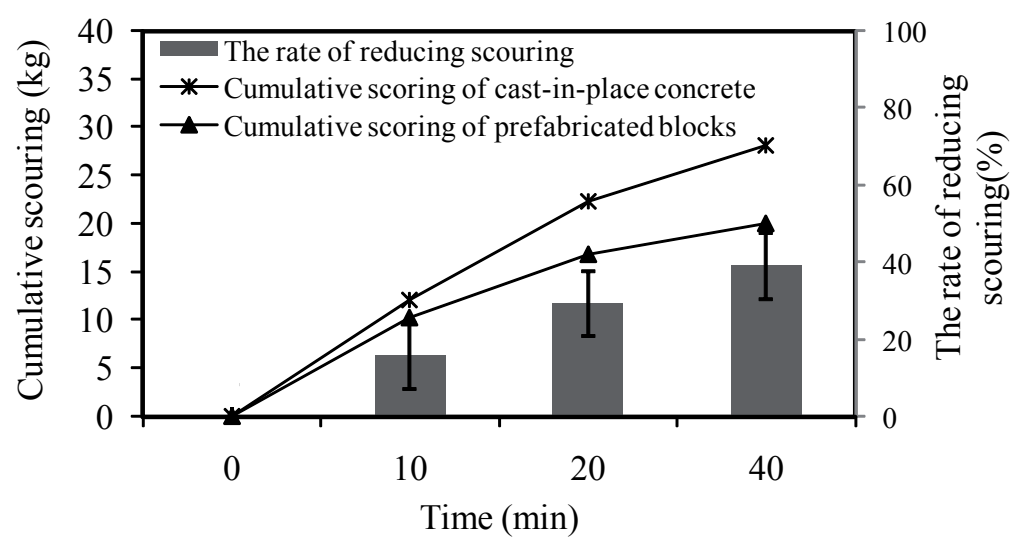

Fig. 7. Change in cumulative scouring level for different structural types over time. The cumulative scouring of the prefabricated blocks is the mean of the cumulative scouring of the four types of blocks and cast-in-place concrete.

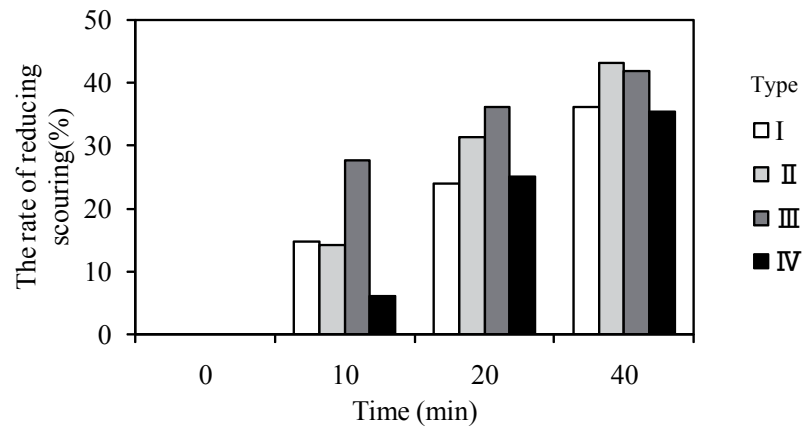

Fig. 8. The rates of reducing scouring with prefabricated blocks laid on the slope over time.

formed by the built-in regular hexagonal blocks and the built-in concrete cross blocks had slightly higher water scouring resistance. It can be concluded that the slopes of the prefabricated blocks play an important role in reducing the amount of scouring, and the different types of slopes of prefabricated blocks have different potentials for soil conservation and scouring resistance.

Because the built-in regular hexagon member showed the best results for reducing the flow rate of inshore water and improving scouring resistance and soil conservation in revetments, it was used as a typical experimental object in different scouring tests under test conditions from case 6 to case 9. Fig. 9a) shows that the scouring level of blocks of slope under the water level of $0.5 \mathrm{~m}$ is less over time than that under the water level of $1 \mathrm{~m}$ in case 2 and case 6 . As the water level increases, the soil scouring amounts of blocks of slope also increases significantly. The higher the water level, the weaker the scouring resistance of the blocks. The difference between the cumulative scouring amounts of blocks at a gradient of 1:2, and that of precast blocks at a gradient of 1:3 grows larger over time in case 2 and case 9 (Fig. 9b). After $40 \mathrm{~min}$, the soil scouring level at a gradient of 1:2 is 1.59 times that at a gradient of 1:3. The slope has a very obvious influence on the scouring resistance of the slope protection, that is, the greater the slope, the worse the scouring resistance of the prefabricated slope protection. Fig. 9c) shows that the initial scouring level at a higher flow rate increases significantly, and the amount of erosion increases rapidly at first and then decreases gradually in $0.7 \mathrm{~m} / \mathrm{s}$ (case 7), $1.2 \mathrm{~m} / \mathrm{s}$ (case 2), and $2.0 \mathrm{~m} / \mathrm{s}$ (case 8). This shows that soil particles can be carried away by decreased water flow over time After $40 \mathrm{~min}$, the total scouring level for the $2.0 \mathrm{~m} / \mathrm{s}$ water flow is almost 3 times that of the $0.7 \mathrm{~m} / \mathrm{s}$ water flow. Therefore, water flow velocity, designed gradient,
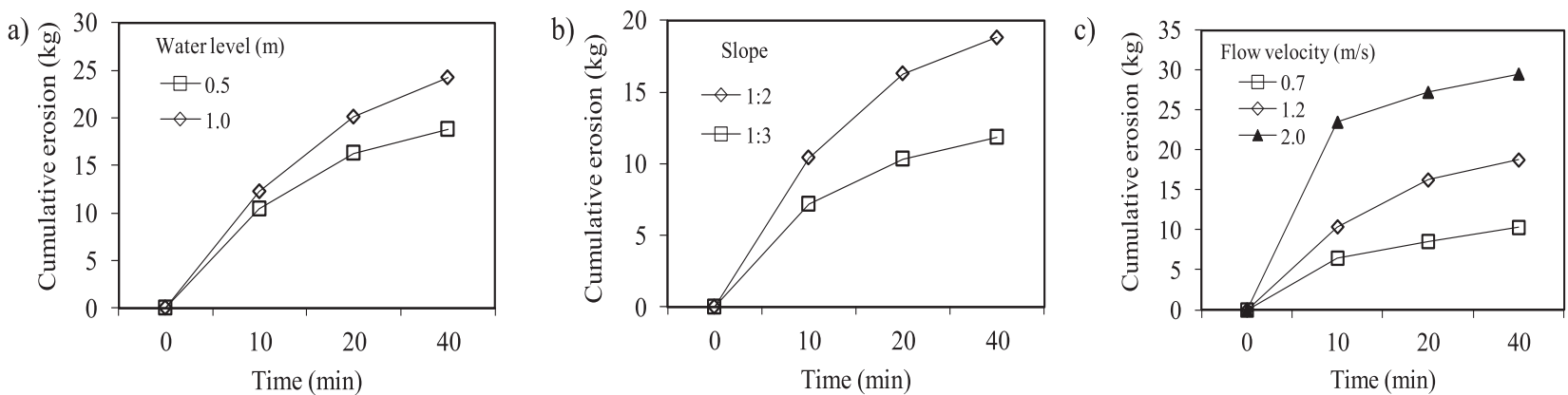

Fig. 9. Variation in cumulative scouring level over time under different flow velocities, water levels, and slopes. 


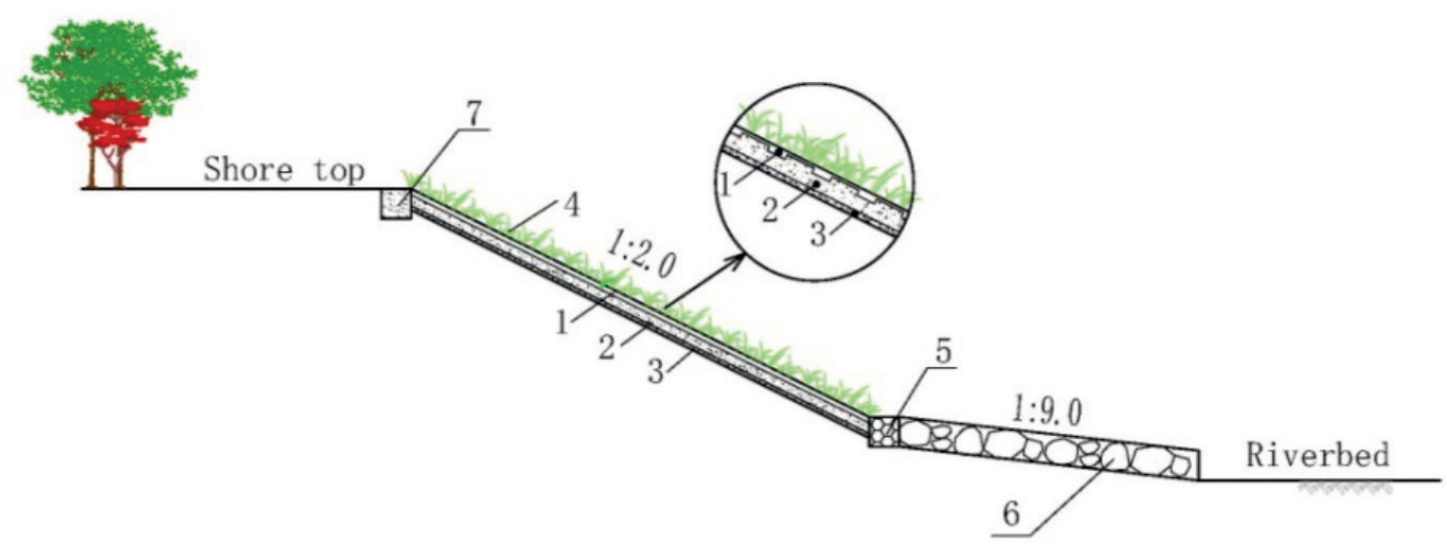

Fig. 10. Standard construction cross-section. 1.Casing soil; 2. Prefabricated grass-planting concrete; 3. Sand- gravel cushion; 4. Herbs; 5. Gabion; 6. Stone paving; 7. Cast-in-place top concrete.
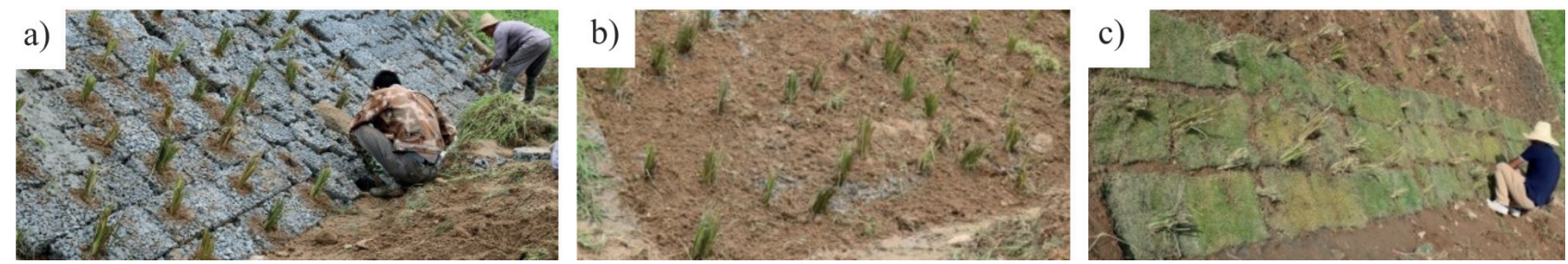

Fig. 11. Process of construction (a) Set up of prefabricated grass-planting concrete; b) Covering soil; c) Covering Bermudagrass turf and planting Vetiveria.).

and water level are the main factors to be considered in designing revetments with prefabricated grass-planting concrete blocks, and flow velocity is the most sensitive of the three factors.

\section{Field Construction and Analysis}

A cross-section of the slope using prefabricated blocks is shown in Fig. 10. The application of prefabricated blocks includes the processes shown in Fig. 11. The first step was the manufacturing and curing of blocks, then the riverbank was cleaned and flattened. The gabion foundation and cast-in-place top concrete were constructed, and then blocks were installed on the slope of the riverbank after the gravel cushion was laid. Soil with seeds was then applied ( $5 \mathrm{~cm}$ thick) on top. Finally, the surface of the slope was covered with black geotextile for protection from the harsh rays of the sun and rain scouring, and it was cured and regularly watered. Vetiveria and Bermudagrass, which have developed roots, strong vitality, and cold and drought tolerance, were selected for grass planting and slope protection. The roots of these grasses grow well, and play an anchoring role after penetrating the slope, thus unifying the slope surface and shore base.

Vegetation coverage was systematically measured by the normalized difference index (NDI) method via the use of digital photographs [30]. The thickness of the soil covering on the slope when different types of prefabricated blocks were used was measured. Five measuring points of the cross-sections for each type of block were selected, and they were distributed in the upper, middle, and lower parts of the slope. Fig. 12 presents the average thickness calculated for each type of block. After a flooding period, the average surface thickness of the soil covering was $4.4 \mathrm{~cm}$, and the thickness of the surface covering over $85 \%$ of the area was greater than $3 \mathrm{~cm}$. The average thickness of the

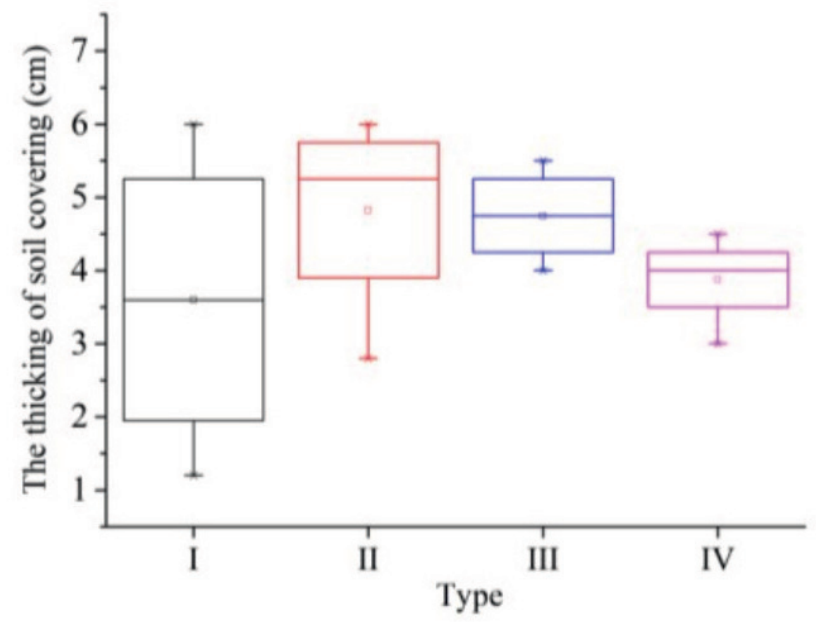

Fig. 12. The thickness of soil covering for four types of prefabricated grass-planting concrete. 


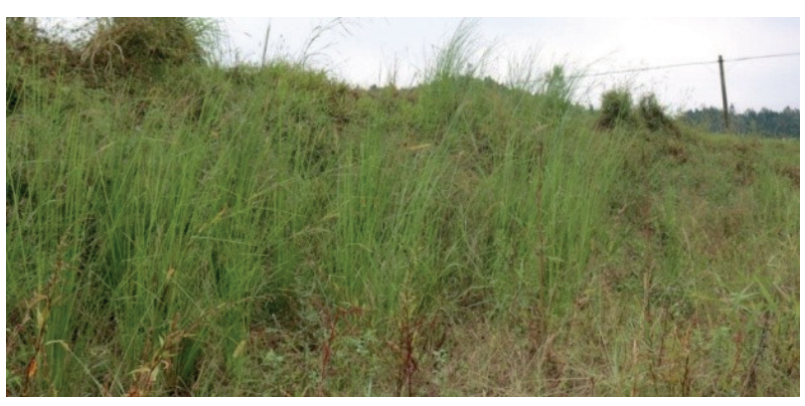

Fig. 13. Effects of revetment after one year.

prefabricated concrete blocks was greater than that of flat concrete, which was only $1.2 \mathrm{~cm}$. The soil covering with a smaller thickness was distributed at lower parts of the slope, because these parts were scoured for a longer amount of time and with a higher water level. The thickness of the soil covering at the middle parts of the slope varied only slightly, and even exceeded $5 \mathrm{~cm}$ due to the downward movement of the upper soil covering that was affected by water flow and rain erosion. According to the demonstration applications, this revetment structure had good soil conservation and scouring resistance, with vegetation coverage up to $95 \%$ on average (see Fig. 13). Compared with that of the cast-in-place grass-planting concrete, the vegetation coverage of the prefabricated concrete blocks was up to $86 \%$ higher. Therefore, prefabricated grassplanting concrete can effectively reduce the flow rate of inshore water, improve scouring resistance, and increasing the vegetation coverage in revetments. The results provide new river revetment techniques for flood control, ecosystem protection, and environment beautification.

\section{Conclusions}

In this study, the concept of prefabricated grassplanting concrete was proposed, and four types of blocks were tested. Through physical modeling and practical application, the precipitation flow velocity, scouring resistance, and soil conservation on the coastal slope of revetments were quantitatively analyzed, which provided important technical support for revetment design and ecologically friendly riverbanks. The following conclusions can be drawn:

1. The concave-convex structure of prefabricated grass-planting concrete on a three-dimensional slope can better reduce inshore flow velocity. The flow velocity-reducing capacity of prefabricated blocks with different types is different.

2. The rate of scouring reduction with different prefabricated blocks laid on the slope was in the range of $35 \%-43 \%$; thus, the results were similar. The prefabricated revetment blocks were demonstrated to have superior anti-scouring effects. The slopes formed by the built-in regular hexagon blocks and the built- in concrete cross blocks had slightly higher water scouring resistance. The concave-convex structure can effectively prevent soil from sliding, and effectively maintain the planting soil and provide rich nutrition and a rich growing environment for vegetation.

3. Flow velocity, design slope, and water level are the key factors that affect the anti-scour performance of prefabricated grass-planting concrete revetments, and should be considered in the design process. In addition, the design of through-holes or grooves, and plant anchorage measures can also be considered. Self-locking and overall interlocking can improve the ability of prefabricated blocks to resist different degrees of water erosion in order to adapt to the continuous fluctuation in the slope gradient, and deformation of the slope foundation.

4. Four types of prefabricated grass-planting concrete blocks were validated for in-situ application. The average vegetation coverage ratio reached 95\% after one year. This study provides theoretical data and a factual basis for promoting the innovation and application of grass-planting concrete technology.

\section{Acknowledgments}

This research was supported by the National Natural Science Foundation of China (No. 51869012), the Key Projects of Jiangxi (No. 20201BBG71002), the Science and Technology Project of Water Resources Department of Jiangxi province (No. 202022TGKT08, No. KT201646), and Jiangxi Key Research and Development Program (No. 20171BBG70046).

\section{Conflict of Interest}

The authors declare no conflict of interest.

\section{References}

1. PARK S.B., KIM J.H. Mechanical Properties of Carbon Fiber Reinforced Porous Concrete for Planting. International Journal of Concrete Structures \& Materials, 14 (2), 34, 2002.

2. KIM H.H., KIM C.S., JEON J.H., PARK, C.G. Effects on the Physical and Mechanical Properties of Porous Concrete for Plant Growth of Blast Furnace Slag, Natural Jute Fiber, and Styrene Butadiene Latex Using a Dry Mixing Manufacturing Process Materials. (9), 84, 2016.

3. ZHANG S.B., SHI Y.X., QU T.J., ZHANG Y.G., LIU W., WANG K. Experimental research on greengrowing concrete and its application. Concrete, 48 (8), 125, 2012.

4. GAO J.M., JI B.H., WU C.D., LIU H.F. Experimental study on properties of green-growing porous concrete, Journal of Jiangsu University (Natural Science Edition), 26 (4), 345, 2005.

5. JOSHAGHANI A., RAMEZANIANPOUR A.A., ATAEI O., GOLROO A. Optimizing pervious concrete pavement 
mixture design by using the Taguchi method, Constr. Build. Mater, 101, 317, 2015.

6. MARTIN W.D., KAYE N.B., PUTMAN B.J. Impact of vertical porosity distribution on the permeability of pervious concrete. Construction and Building Materials, 59, 78, 2014

7. TIAN L., PENG Z.M., QUAN H.Z., SONG H. Physical properties and vegetative adaptation of eco-porous concrete. Bulletin of the Chinese Ceramic Society, 35 (10), 33816, 2016.

8. ZHONG W.L., LI Z.Q., ZHU C.M., ZHU W. Experimental study on mechanical and planting properties of porous ecological concrete. Concrete, (6), 131, 2012.

9. QUAN H.Z. Coexistence of porous ecological concrete with plants. Bulletin of the Chinese Ceramic Society, 7 (34), 261, 2015.

10. ZHANG G., YIN J., LI S. Gradation characteristic analysis of vegetation-type porous concrete. Materialwiss Werkstofftech, 50, 1399, 2019.

11. LIAN C., ZHUGE Y., BEECHAM S. The relationship between void ratio and strength for porous concrete. Construction and Building Materials, 25, 4294, 2011.

12. LIAN K. Manufacture and capability tests of high fly ash content planting eco-concrete. Concrete, (3), 151, 2016.

13. GOKCE A., BEYAZ C., OZKAN H. Influence of fines content on durability of slag cement concrete produced with limestone sand. Construction and Building Materials, 111, 419, 2016

14. CHEN S.K., YANG Q., LIU Q.C., GUO L., WANG L. Experiment on strength and permeability of recycled aggregate pervious concrete. Transactions of the Chinese Society of Agricultural Engineering (Transactions of the CSAE), 33 (15), 141, 2017.

15. CHEN F., XU Y., WANG C., MAO J. Effects of concrete content on seed germination and seedling establishment in vegetation concrete matrix in slope restoration. Ecological Engineering, 58, 99, 2013.

16. JANG J.G., AHN Y.B., SOURI H., LEE H.K. A novel eco-friendly porous concrete fabricated with coal ash and geopolymeric binder: Heavy metal leaching characteristics and compressive strength. Construction and Building Materials, 79, 173, 2015.

17. PARK S.B., KIM J.H., SEO D.S. Physical and mechanical properties of carbon fiber reinforced smart porous concrete for planting. Proceedings of SPIE - The International Society for Optical Engineering, 5765, 1073, 2005.

18. CHENG J.F., LUO X.Y., SHEN Z.Y., GUO X.Q. Study on vegetation concrete technology for slope protection and greening engineering. Polish Journal of Environmental Studies, 29, 4017, 2020 .
19. LEE J.Y., PARK J.S., PARK C.G. Effect of reinforcing fiber on mechanical properties and chemical resistance of porous concrete with hwang-ton, Journal of the Korean Society of Civil Engineers A, 31 (2A), 105, 2011.

20. TANG, W., MOHSENI, E., WANG, Z. Development of vegetation concrete technology for slope protection and greening. Construction and Building Materials, 179, 605, 2018.

21. LI D.L., DU L., LI Y.J., XU W., LIU W. Model test on wave dissipation effect of roughened embankment with permeable prefabricated block for slope protection. Transactions of the Chinese Society of Agricultural Engineering (Transactions of the CSAE), 33 (4), 146, 2017.

22. ZHAN D., YANG J. Application of prefabricated concrete block in river revetment, China Water Transport, 18 (3), 161, 2018.

23. NATIONAL STANDARD OF THE PEOPLE'S REPUBLIC OF CHINA, Common Portland cements: The General Administration of Quality Supervision, GB 175, Inspection and Quarantine (GAQSIQ) of and CNS Management Committee (CNSMC) the People's Republic of China, 2007.

24. YAO A.L. The Mixture's Proportion Design Method and Frost Resistance of Porous Concrete. Hans Journal of Civil Engineering, 7 (2), 168, 2018.

25. NATIONAL STANDARD OF THE PEOPLE'S REPUBLIC OF CHINA, Code for design of levee project. GB 50286, Ministry of Housing and Urban-Rural Construction of the People's Republic of China, General Administration of Quality Supervision, Inspection and Quarantine of the People's Republic of China, 2013.

26. XIA ZY., ZHANG L., CHEN Y., XUE H.L., XU W.N. Vetiver root-soil contact characteristics and pull-out model. Journal of Hydroecology, 37 (4), 36, 2016.

27. YAO A., HAO D., ZHANG X., HU Z., HAO R., TAO Y. Optimum design and performance of porous concrete for heavy-load traffic pavement in cold and heavy rainfall region of NE China. Advances in Materials Science and Engineering, 2018, 1, 2018.

28. KIM H.H., KIM C.S., JEON J.H., PARK C.G. Effects on the physical and mechanical properties of porous concrete for plant growth of blast furnace slag, natural jute fiber, and styrene butadiene latex using a dry mixing manufacturing process. Materials, 9 (2), 84, 2016.

29. LI X.D., LI K., WENG S.F. Research on lowering the $\mathrm{pH}$ and EC of porous concrete and plant growth test. New Building Materials, (1), 49, 2017.

30. REN J., BO Y.H., WANG J.D. An efficient method for extraction vegetation coverage for digital photographs. Remote sensing technology and application, 25 (5), 719, 2010. 